\title{
PELATIHAN PENGELOLAAN KEUANGAN DESA DI KECAMATAN SEBERIDA KABUPATEN INDRAGIRI HULU
}

Abrar ${ }^{1}$, Dian Saputra ${ }^{1}$,Raja Ria Yusnita ${ }^{1}$, Lintang Nur Agya ${ }^{1}$

${ }^{1}$ Program Studi Akuntansi, Fakultas Ekonomi dan Bisnis, Universitas Islam Riau, Jl. Kaharuddin Nst 113, Pekanbaru, Riau, Indonesia

*Penulis koresponden: saputradian@eco.uir.ac.id

\begin{tabular}{l}
\hline \hline Info Artikel \\
\hline Riwayat: \\
Dikirim 1 Desember 2021 \\
Direvisi 31 Desember 2021 \\
Diterima 10 Januari 2022 \\
\hline
\end{tabular}

\section{Kata Kunci:}

Keuangan

Desa

Sektor Publik

Akuntansi

\begin{abstract}
Abstrak
Pada tahun 2019 Provinsi Riau mendapatakan alokasi dana desa bersumber dari APBN sebesar Rp. 1.436.685.874 yang diterima oleh 1.591 desa dari 10 Kabupaten. Namun, berdasarkan laporan realisasi serapan anggaran pemerintah daerah/desa masih di kisaran 75\%-85\%. Realisasi serapan anggaran yang belum optimal dapat menggambarkan tingkat pertumbuhan ekonomi desa yang lambat. Desa-desa ini memiliki potensi yang sangat besar jika tata kelola keuangan desanya dilakukan secara optimal. Pengabdian ini akan dilakukan untuk membantu pemerintah desa yakni perangkat desa dalam mengelola keuangan desa secara tepat guna dan mencapai serapan anggaran yang optimal. Metode pelaksanaan kegiatan pengabdian masyarakat yaitu dalam bentuk Pelatihan untuk menyampaikan materi serta diskusi dengan perangkat desa yang ada di Kecamatan Siberida Kabupaten Indragiri Hulu. Permasalahan sering tejadi dikarenakan pemahaman yang kurang dari perangkat desa tentang proses perencanaan, penatusahaan, pelaporan dan pertanggung jawaban. Dalam proses perencanaan desa masih mengacu pada anggaran sebelumnya. Sedangkan Ketika penatausahaan dari realisasi anggaran desa masih belum mengetahui mengenai administrasi apa saja yang dibutuhkan. Pelaporan dan pertanggungjawaban dari dana desa masih belum sesuai dengan standar yang telah ditetapkan oleh pemerintah.
\end{abstract}

\section{PENDAHULUAN}

Berdasarkan Undang-Undang Nomor 6 Tahun 2014 tentang Desa, merupakan kumpulan masyarakat yang memiliki kesatuan yang terikat dengan hukum dan dibatasi oleh wilayah yang berwenang sehingga harus mengikuti aturan untuk mengurus urusan pemerintahan dan tatanan desa. Pemerintahan Desa adalah tempat terjadinya penyelenggaraan yang didalamnya berisi kepentingan masyrakat dalam tatanan pemerintahan. Pemerintahan desa berfungsi sebagai atasan yang membawahi kepala desa dan dibantunya oleh perangkat desa sebagai terselenggaranya Pemerintahan Desa. Pembangunan kawasan pedesaan merupakan upaya mempercepat dan meningkatkan kualitas pelayanan, pembangunan, dan pemberdayaan masyarakat di desa melalui pendekatan partisipatif.

Dalam melaksanakan pembangunan kawasan pedesaan tersebut diperlukan pendanaan/pendapatan desa. Desa mempunyai sumber pendapatan desa yang terdiri dari pendapatan asli desa, bagi hasil pajak daerah dan retribusi daerah kabupaten/kota, bagian dari dana perimbangan keuangan pusat dan daerah yang diterima oleh kabupaten/kota, alokasi anggaran dari Anggaran Pendapatan dan Belanja Negara (APBN), bantuan keuangan dari Anggaran Pendapatan dan Belanja Daerah (APBD) Provinsi dan APBD Kabupaten/Kota, serta hibah dan sumbangan tidak mengikat dari berbagai pihak.

Berdasarkan hak dan kewajiban desa, keuangan desa adalah semua hak dan kewajiban desa yang dapat diukur menggunakan uang dan barang, maka dari itu desa diberikan kewenangan dan 
sumber dana yang mencukupi agar dapat megurus potensi yang dimiliki oleh desa guna meningkatkan ekonomi dan kesejahteraan masyarakat desa. Pemerintah desa dituntut untuk meningkatkan kinerja secara optimal serta mampu menciptakan tujuan masyarakar desa yang sejahtera sebagai suatu implikasi dari penerapan ekonomi desa yang mengedepankan akuntabilitas kinerja dan peningkatan pelayanan publik. Namun, desa-desa di Indonesia masih menemui banyak kendala dalam proses optimalisasi sumber-sumber pendapatan tersebut. Kendala yang banyak ditemukan dalam hal pengelolaan dana desa antara lain permasalahan dalam hal pengalokasian dana desa per desa yang tidak sesuai dengan formulasi ketentuan, penggunaan dana desa dan ADD yang tidak sesuai peruntukan, serta serapan anggaran daerah/desa yang masih rendah.

Pada tahun 2019 Provinsi Riau mendapatakan alokasi dana desa bersumber dari APBN sebesar Rp. 1.436.685.874 yang diterima oleh 1.591 desa dari 10 Kabupaten. Namun, berdasarkan laporan realisasi serapan anggaran pemerintah daerah/desa masih di kisaran 75\%-85\%. Realisasi serapan anggaran yang belum optimal dapat menggambarkan tingkat pertumbuhan ekonomi desa yang lambat.

Kecamatan Seberida merupakan salah satu kecamatan yang ada di Provinsi Riau yang memilik desa-desa. Desa-desa ini memiliki potensi yang sangat besar jika tata kelola keuangan desanya dilakukan secara optimal. Pengabdian ini akan dilakukan untuk membantu pemerintah desa yakni perangkat desa dalam mengelola keuangan desa secara tepat guna dan mencapai serapan anggaran yang optimal.

Berdasarkan penjelasan latar belakang di atas, rumusan masalah pada pengabdian masyarakat ini adalah terbatasnya kemampuan pemerintah desa/perangkat desa dalam tata kelola keuangan desa. Adapun tujuan dilakukan pengabdian masyarakat pada Kecamatan Seberida adalah untuk memberikan pengetahuan dan meningkatkan kemampuan perangkat desa dalam tata kelola keuangan desa. Selain itu juga ditujukan untuk meningkatkan serapan anggaran pendapatan yang optimal serta tepat guna.

\section{METODE PELAKSANAAN}

Tempat kegiatan pengabdian masyarakat ini akan dilaksanakan di Kantor Kecamatan Siberida Kabupaten Indragiri Hulu. Adapun pelaksanaan kegiatan ini dilakukan pada hari Rabu tanggal 24 November 2021 dari pukul 08.00 s/d Pukul 17.30 WIB. Metode pelaksanaan kegiatan pengabdian masyarakat yaitu dalam bentuk pelatihan untuk menyampaikan materi serta diskusi dengan perangkat desa yang ada di Kecamatan Siberida Kabupaten Indragiri Hulu. Berikut rincian waktu pelaksanaan kegiatan tersebut dapat dilihat pada Tabel 1.

Kegiatan pelatihan pengelolaan keuangan utuk perangkat desa di Kecamatan Siberida Kabupaten Indragiri Hulu dilaksanakan pada hari Rabu 24 November 2021 dari pukul 13.00 s/d 17.30. Dihadiri oleh para perangkat desa yang terdiri dari kepala-kepala desa dan bendahara-bendahara desa yang ada di Kecamatan Siberida Kabupaten Indragiri Hulu. Kegiatan ini juga melibatkan mahasiswa dengan tujuan untuk memberikan pengalaman dan meningkatkan pemahaman mahasiswa mengenai penerapan akuntansi desa.

Kegiatan ini diselenggarakan di Kantor Camat Siberida. Kegiatan dimulai dengan kata sambutan oleh Ketua Pelaksana Kegiatan dan Kepala Kantor Camat Siberida dengan suasana kekeluargaan dan dilanjutkan dengan doa bersama agar kegiatan berlangsung dengan hikmat. Penyampaian mengenai materi pelatihan disampaikan oleh ketua pelaksana yang berlangsung sebanyak 2 sesi, dilanjutkan dengan sesi diskusi dan tanya jawab. Materi yang disampaikan berhubungan dengan permasalahan pengelolaan keuangan desa yang masih dihadapi oleh desa. Kegiatan ditutup dengan penyampaian kesimpulan dari permasalahan yang telah dibahas.

Tabel 1. Rincian Kegiatan Pengabdian Masyarakat

\begin{tabular}{cccc}
\hline No & Agenda & Waktu & Keterangan \\
\hline 1 & Brefing sebelum keberangkatan & $08.00-08.30$ & Tim \\
2 & Menuju Lokasi Pengabdian Kecamatan & $08.30-12.00$ & Mahasiswa \& Tim \\
3 & Siberida Kab. Indragiri Hulu & $12.30-13.00$ & All \\
& Persiapan Pembukaan & & MC \\
4 & Pembukaan & $13.00-13.20$ & \\
\hline
\end{tabular}




\begin{tabular}{|c|c|c|c|c|}
\hline & \multicolumn{4}{|l|}{$\begin{array}{c}\text { Sambutan Kepala Kantor Camat } \\
\text { Siberida }\end{array}$} \\
\hline \multicolumn{5}{|c|}{ Lanjut Materi } \\
\hline 5 & Sesi I Pemaparan materi & $13.20-15.00$ & $\begin{array}{c}\text { Oleh } \\
\text { dipandu } \\
\text { moderator }\end{array}$ & $\begin{array}{l}\text { Pemateri } \\
\text { Oleh }\end{array}$ \\
\hline 6 & Ishoma & $15.00-15.30$ & \multicolumn{2}{|c|}{ All } \\
\hline 7 & Sesi II Tanya Jawab \& Diskusi & $15.30-17.00$ & \multicolumn{2}{|c|}{ Dipandu moderator } \\
\hline 8 & Penutupan & $17.00-17.30$ & \multicolumn{2}{|c|}{$\mathrm{MC}$} \\
\hline 9 & Persiapan pulang & $17.30-18.00$ & \multicolumn{2}{|c|}{ All } \\
\hline 10 & Pulang menuju Pekanbaru & $18.00-23.00$ & \multicolumn{2}{|c|}{ All } \\
\hline
\end{tabular}

\section{HASIL DAN PEMBAHASAN}

Hasil kegiatan Pengabdian Masyarakat tentang pengelolaan keuangan desa di Kecamata Siberida Kabupaten Indragiri Hulu yang dilaksanakan pada hari Rabu 24 November 2021 di Kantor Camat Siberida, memberikan beberapa poin pembahasan sesuai dengan hasil survey awal pelaksana mengenai permasalahan pengelolaan keuangan desa yang biasa ditemukan pada desa-desa. Proses pengelolaan keuangan desa dimulai dari perencanaan, pelaksanaan, penatausahaan, pelaporan dan pertanggungjawaban keuangan desa. Dimana setiap desa dapat mengatur sendiri dana desa yang diberikan. Namun permasalahan sering tejadi dikarenakan pemahaman yang kurang dari perangkat desa tentang proses perencanaan, penatusahaan, pelaporan dan pertanggung jawaban. Dalam proses perencanaan desa masih mengacu pada anggaran sebelumnya. Sedangkan Ketika penatausahaan dari realisasi anggaran desa masih belum mengetahui mengenai administrasi apa saja yang dibutuhkan. Pelaporan dan pertanggungjawaban dari dana desa masih belum sesuai dengan standar yang telah ditetapkan oleh pemerintah.

\section{KESIMPULAN}

Kegiatan dilaksanakan pada hari Rabu 24 November 2021, dimulai dengan kata sambutan oleh pelaksana kegiatan dan Kepala Kantor Camat Siberida Kabupaten Indragiri Hulu, dilanjutkan dengan doa bersama. Kemudian penyampaian materi pelatihan mengenai penerapan akuntansi desa kepada perangkat desa yang tediri dari kepala desa dan bendahara. Kegiatan ini untuk memberikan pemahaman kepada perangkat desa agar dalam pengelolaan keuangan desa agar tercipta good corporate governance.

\section{DAFTAR PUSTAKA}

Soemantri, Bambang Trisantono. 2010. Pedoman Penyelenggaraan Pemerintahan Desa. Fokusmedia, Bandung.

Peraturan Menteri Dalam Negeri Republik Indonesia Nomor 113 Tahun 2014 Pemerintahan Desa.

Peraturan Pemerintah Republik Indonesia Nomor 72 Tahun 2005 Peraturan Pemerintah Republik Indonesia Nomor 72 Tahun 2005 Tentang Desa.

Undang-Undang Republik Indonesia Nomor 6 Tahun 2014 tentang Desa. 